\title{
Analisis Kemampuan Berpikir Kritis Kelas IV B Tema Kayanya Negeriku Melalui Strategi Pembelajaran Jeopardy Review
}

\author{
Nukhbatul Bidayati Haka \\ UIN Raden Intan Lampung \\ nukhbatulbidayatihaka@radenintan.ac.id \\ Leni Rosida \\ UIN Raden Intan Lampung \\ Lenirosida05@gmail.com
}

\begin{abstract}
This study aims to improve the ability to think critically in class IV SDN 1 Sukamulya in science subjects through the application of learning strategies jeopardy review. This type of research is a quantitative study using the method research Quasy Experimental Design and the design used is pretestpoststest design. The population in this study were students of class IV (A, B, dan C) SDN 1 Sukamulya Academic year 2019/2020. Totaling 85 students, while the samples in this study were group IVB as the experimental class and class IVC as the control class. The sample was taken using cluster random sampling technique. In this study, the data collection tools used were test, observation, and dokumentation. The instrumen test used was critical thinking essay questions. Hypothesis testing using statistical analysis Independent Sample t-Test. Based on the result of the study obtained the average value of the experimental class 83,00 while the average value of the control class was 76,28. Results hypothesis testing using the analysis of Independent Sample t-Test with a significance level $5 \%(0,05)$, i,e. $0,000<0,05$ so that $\mathrm{H}_{0}$ is rijected and $\mathrm{H}_{\mathrm{a}}$ is accepted, so it can be drawn conclusion that there is an influence of the jeopardy review learning strategy on critical thinking skills of grade IV students on material wealth of energy sources in Indonesia at SDN 1 Sukamulya Academic Year $2019 / 2020$.
\end{abstract}

Keywords: Learning Strategies; Jeopardy Review; Critical Thinking; Natural Science 


\begin{abstract}
Abstrak
Penelitian ini bertujuan untuk meningkatkan kemampuan berpikir kritis kelas IV SDN 1 Sukamulya pada materi IPA dalam tema kayanya negeriku dengan cara menggunakan strategi pembelajaran jeopardy review pada saat proses pembelajjaran berlangsung. Jenis penelitian yang digunakan oleh peneliti adalah penelitian kuantitatif dengan menggunakan metode penelitian Quasy Eksperimental Group Design dan menggunakan desain penelitian yakni Pretest-Posttest Group Design. Populasi pada penelitian ini adalah peserta didik kelas IV (A, B, dan C) SDN 1 Sukamulya Tahun Pelajaran 2019/2020 yang prserta didiknya secara keseluruhan berjumlah 85 peserta didik, sampel pada penelitian ini yakni kela IV B sebagai kelas penelitian dan kelas IV C berperan sebagai kelas kontrol. Sampel ini diambil dengan menggunakan cara cluster random sampling. Pada penelitian ini instrumen yang digunakan yaitu observasi, dan test, serta dokumentasi. Instrument test yang digunakan yakni soal dalam bentuk essay untuk mengukur kemampuan berpikir kritis. Uji hipotesis pada penelitian ini menggunakan analisis data statistik Independent Sample t-Test. Berdasarkan hasil penelitian diperoleh hasil nilai rata-rata kelas eksperimen sebesar 83,00 sedangkan nilai rata-rata kelas kontrol sebesar 76,28. Hasil uji hipotesis menggunakan analisis Independent Sample t-Test dengan menggunakan taraf signifikasi $0,05(5 \%)$, yaitu $0,000<0,05$ sehingga hasilnya $\mathrm{H}_{0}$ ditolak dan $\mathrm{H}_{1}$ diterima, sehingga dapat disimpulkan bahwa terdapat pengaruh strategi pembelajaran jeopardy review terhadap kemampuan berpikir kritis peserta didik kelas IVB pada materi IPA tema kayanya negeriku di SDN 1 Sukamulya Tahun Pelajaran 2019/2020.
\end{abstract}

\title{
Kata Kunci: Strategi Pembelajaran; Jeopardy Review; Berpikir Kritis; IPA
}

\section{PENDAHULUAN}

Pendidikan adalah upaya manusia untuk "memanusiakan manusia". Pendidikan juga merupakan semua usaha memberdayakan kemampuan yang dimiliki murid, melalui cara membuat suasana pembelajaraan yang sesuai karakter murid. ${ }^{1}$ Menjadikan manusia yang seutuhnya sesuai tujuan manusia hidup di bumi. Pendidikan menjadi suatu aspek utama sebagai upaya untuk mempersiapkan manusia yang berkualitas dan mampu menghadapi proses dan tantangan kehidupan masyarakat dalam berbangsa dan bernegara, dan

\footnotetext{
'Zulfani Sesmiarni, 'Kecerdasan Jamak Dalam Pembelajaran IPA Di Sekolah Dasar', TERAMPIL Jurnal Pendidikan Dan Pembelajaran Dasar, Vol. 1, No. .2 (2014), 180.
} 
pendidikan ini mempunyai posisi yang penting dalam membuat masyarakat sadar mengenai perubahan sosial. ${ }^{2}$ Potensi yang semakin tergali akan menjadi suatu bakat yang baik, melalui bakat yang baik seseorang dapat menghasilkan sesuatu, baikbarang ataupun jasa yang bisa bermanfaat untuk hidupnya sendiri dan orang disekelilingnya. Kebermanfaatan seseorang bagi lingkungan sekitarnya, bagi bangsanya, bagi negaranya dan bagi agamanya merupakan contoh dari ketercapaian suatu tujuan dari pendidikan selama ini.

Pendidikan nasional bertujuan untuk membuat kualitas setiap manusia lebih baik, menjadi manusia yang bertaqwa kepada Tuhan dan bisa meningkatan kebudayaan yang baik sebagai warga negara Indonesia yang berjiwa pancasila serta memiliki semangat dan pemahaman yang baik, sehingga bisa kuat, terampil, cerdas, bisa mengembangkan dan menerapkan dengan baik sikap demokratis, bisa menjaga hubungan baik antara sesama, sehaat jasmani dan rohani. ${ }^{3}$ Pada dasarnya tujuan pendidikan memuat gambaran mengenai nilai-nilai yang baik dan benar mengenai kehidupan. Hal ini seperti yang tertuang pada UU Nomor 20 Tahun 2003 Pasal 1 ayat 1 mengenai Sistem Pendidikan Nasional Indonesia yakni:

Pengembangan manusia menjadi manusia yang memiliki ketakwaan kepada Tuhan Yang Maha Esa, berbudi baik, mempunyai pengetahuan dan keterampilan sehat jasmani dan rohaninya, serta mempunya rasa tanggung jawab terhadap dirinya, masyarakat, dan nusa serta bagsanya. Hal-hall diatas adalah tujuan pendidikan nasional yang dijelaskan dalam UU Nomor 20 Tahun 2003 Pasal 1 Ayat 1. ${ }^{4}$

Pendidikan beserta pembelajaran adalah suatu paket yang terpisah. Pendidikan adalah suatu unsur mendasar dari sebuah proses pelaksanaan pendidikan. Konsep pembelajaran yang baik menentukan kualitas suatu

\footnotetext{
${ }^{2}$ Hendri Purbo Waseso, 'Studi Kritis Terhadap Kurikulum MI/SD 2013', Jurnal Terampil, 4 (2017), 175.

${ }^{3}$ Nur Uhbiyati, Abu Ahmadi, Ilmu Pendidikan, (Jakarta: Rineka Cipta, 2015), 198.

${ }^{4}$ Tim Redaksi, Undang-Undang Nomor 20 Tahun 2003 Tentang Sistem Pendidikan Nasional, (Jakarta: Sinar Grafika, 2016), 2.
} 
pendidikan. ${ }^{5}$ Jadi pembelajaran dan pendidikan adalah satu kesatuan yang mempengaruhi satu sama lain. pendidikan yang berkualitas juga dipengaruhi oleh profesionalisme guru pada saat proses belajar mengajar. Pada saat proses belajar mengajar berlangsung murid membutuhkan pendidik sebagai sumber belajar serta bahan belajar, menjadi pendidik profesional guru harus dapat mengaktualisasi diri yang sesuai apa kemampuan dirinya. Jadi baik tidaknya kualitas pendidikan dipengaruhi salah satu faktor yaitu pendidi.

Dalam proses meningkatkan kualitas pendidikan strategi belajar yang diajarkan harus sesuai kurikulum yang terapkan. Strategi belajar adalah pola dan prosedur umum aktivitas pembelajaran. ${ }^{6}$ Strategi pembelajaran sama dengan tipe atau jenis pembelajaran yang digunakan. Strategi pembelajaran juga diartikan sebagai pemanfaatan sumber daya pada saat proses pembelajaran serta sebuah rencan untuk menggunakan metode pembelajaran. ${ }^{7}$ Strategi belajar sendiri berfungsi untuk mengatasi berbagai problematika dan kesulitan dalam pelaksanaan pembelajaran. Pada kurikulum 2013 pendidik di tuntut untuk lebih kreatif dan inovatif pada proses pembelajaran. Kemampuan pendidik dalam mengelola kelas dalam proses pembelajaran agar tidak monoton, membosankan, menjenuhkan menjadi sebuah proses pembelajaran yang menyenangkan dan bermakna bagi peserta didik merupakan konteks inovasi pendidik dalam pembelajaran. ${ }^{8}$ Pendidik yang inovatif dapat membuat peserta didik aktif dan senang saat proses belajar mengajar.

Strategi belajar jeopardy review merupakan salah satu strategi pembelajaran yang inovatif. Kemampuan berpikir kritis dan kemampuan

\footnotetext{
${ }^{5}$ Moh Khoerul Anwar, 'Pembelajaran Mendalam Untuk Membentuk Karakter Siswa Sebagai Pembelajar', 02.2 (2017), 98.

${ }^{6}$ Syarif Sumantri, Mohamad, Strategi Pembelajaran Teori dan Praktik Di Tingkat Pendidikan Dasar, (Jakarta: Rajawali Pers, 2016), 39.

${ }^{7}$ Nurdyansyah, Eni Fariyarul Fahyuni, Inovasi Model Pembelajaran Sesuai Kurikulum 2013, (Sidoarjo: Nizamia Learning Center, 2016), 2.

${ }^{8}$ Aris Shoimin, 68 Model Pembelajaran Inovatif dalam Kurikulum 2013, (Yogyakarta: Ar-Ruzz Media, 2017), 21.
} 
berkomunikasi dapat terlatih dengan menggunakan strategi belajar jeopardy review. Masalah-masalah yang kompleks di masa yang akan datang dapat dipecahkan oleh peserta didik dengan menggunakan kemampuan berpikir kritis dan kemampuan berkomunikasi yang dimiliki. ${ }^{9}$ Melalui kemampuan ini seseorang dapat dengan matang menghadapi setiap masalah yang ada pada kehidupannya. Strategi pembelajaran jeopardy review merupakan strategi pebelajaran yang berbasis permainan dan menuntut murid agar mampu berpikir kritis mengenai informasi yang diberikan melalui pertanyaan-pertanyaan yang diberikan. Oleh karena itu strategi belajar yang inovatif dan mampu menyesuaikan dengan karakter murid serta dapat melatih kemampuan berpikir tingkat kritis murid adalah strategi belajar jeopardy review.

Kegiatan yang dilakukan dengan cara berpikir tentang suatu ide ataupun gagasan yang berhubungan dengan konsep yang ada adalah kegiatan berpikir kritis. ${ }^{10}$ Melalui pemberian masalah seseorang akan melakukan aktivitas berpikir sehingga terjadilah berpikir tingkat kritis untuk memecahkan atau menjawab pemasalahan yang ada. Istilah berpikir kritis merujuk pada beberapa hal, yakni: pengetahuan misalnya pertanyaan yang saling berkaitan, kemampuan memberikan pertanyaan dan jawaban berpikir kritis pada waktu yang tepat, serta mampu meggunakan pertanyaan kritis tersebut secra kritis. ${ }^{11}$ Jadi kemampuan yang dimiliki seseorang untuk berpikir secara logis dan kritis guna menyelesaikan masalah yang dihadapi adalah kemampuan berpikir kritis.

\footnotetext{
${ }^{9}$ Muhammad Fikri Hasan, Agus Suyatna, and Wayan Suana, 'Development of Interactive E-Book on Energy Resources to Enhance Student's Critical Thinking Ability', Tadris: Jurnal Keguruan Dan Ilmu Tarbiyah, 3.2 (2018), 109.

${ }^{10}$ Reni Nur Azizah, Pengaruh Pendekatan Proses Dan Kemampuan Berfikir Kritis Terhadap Hasil Belajar Pada Mata Pelajaran Ipa Di Kelas V Mi Terpadu Muhammadiyah Sukarame, 2018, 4.

${ }^{11}$ M. Neil Browne, Stuart M. Keeley, Pemikiran Kritis (Panduan Untuk Mengajukan dan Menjawab Pertanyaan Kritis), (Jakarta: PT Indeks, 2015), 2.
} 
Pelajaran IPA sangat erat kaitannya dengan kemampuaan berpikir kritis seseorang. Ilmu yang mempelajari tentang gejala alam merupakan ilmu yang disebut ilmu pengetahuan alam (IPA). ${ }^{12}$ Bagi murid di sekolah dasar yang mempelajari alam mulai dari fenomena alam disekitarnya. Modal awal bagi anak untuk memecahkan masalah tentang alam disekitarnya yaitu kemampuan berpikir kritis. Oleh sebab itu salah satu strategi yang tepat diterapkan pada saat proses pembelajaran untuk menciptakan proses pembelajaran yang menyenangkan dan bermakna yaitu strategi pembelajaran jeopardy review.

Saat observasi di SDN 1 Sukamulya Kecamatan Palas Kabupaten Lampung Selatan, peneliti melakukan pengamatan mengenai proses pembelajaran di kelas IV pada saat proses belajar mengajar berlangsung. Hasil observasi yang dilakukan, terlihat bahwa pendidik masih menggunakan strategi pembelajaran yang kurang bervariatif seperti ceramah, diskusi kelompok, pemberian tugas. Pendidik juga kurang memakai strategi belajar yang cocok dengan karakter murid, seperti strategi belajar berbasis permainan, berbasis alam dan lain sebagainya. ${ }^{13}$ Kurang bervariatifnya strategi pembelajaran yang diterapkan inilah yang membuat murid kurang aktif saat proses belajar mengajar berlangsung, hal ii enyebabkan kurang terlatihnya kemampuan berpikir kritis muridnya.

Peneliti melakukan wawancara kepada wali kelas IV (A, B, C) SDN 1 Sukamulya. Ada beberapa hal yang peneliti dapat dari hasil wawancara bersama wali kelas IV, yaitu masih kurangnya sarana prasarana yang ada di SDN 1 Sukamulya, seperti belum adanya laboratorium IPA sehingga pendidik sedikit kesulitan jika ingin melakukan praktikum pada saat pelajaran IPA. Selain dari sarana dan prasarana sekolah, pendidik juga kurang menggunakan strategi belajar yang menyenangkan dan menarik saat 19

\footnotetext{
${ }^{12}$ Samatowa Usman, Pembelajaran IPA di Sekolah Dasar, (Jakarta: PT Indeks, 2016),

${ }^{13}$ Hasil Observasi di SDN 1 Sukamulya, tanggal 21 September 2019.
} 
proses belajar mengajar berlangsung. ${ }^{14}$ Pendidik juga terkadang mengalami kendala saat murid mulai merasa bosan dengan penyampaian materi, karena peserta didik kelas IV ini memiliki karakter aktif dan suka bermain, hal ini yang membuat pendidik mengalami kesulitan ketika tidak ada media yang mendukung materi yang sedang dipelajari dan sulit memilih strategi pembelajaran yang akan diterapkan. ${ }^{15}$ Di kelas IV pada siswa dominan aktif dari pada dengan siswi. ${ }^{16}$

Peneliti juga melakukan survei nilai nilai ulangan harian murid kelas IV (A, B, dan C) SDN 1 Sukamulya pada materi IPA, sebagai berikut:

\section{Tabel.I}

Data Nilai Tes Harian Peserta Didik Pada Materi IPA Kelas IV (A, B, C) SDN 1 Sukamulya, Palas Lampung Selatan

Tahun Ajaran 2019/2020

\begin{tabular}{|c|c|c|c|c|c|}
\hline \multirow{2}{*}{ No } & \multirow{2}{*}{ Kelas } & \multicolumn{2}{|c|}{ Nilai } & $\begin{array}{c}\text { Presentase } \\
\text { Ketuntasan (\%) }\end{array}$ & $\begin{array}{c}\text { Jumlah Peserta } \\
\text { Didik }\end{array}$ \\
\cline { 3 - 4 } & & $\mathbf{0} \leq \mathbf{x} \leq \mathbf{6 5}$ & $\mathbf{6 5} \geq \mathbf{x} \leq \mathbf{1 0 0}$ & $53,3 \%$ & 30 \\
\hline 1 & IVA & 14 & 16 & $42,9 \%$ & 28 \\
\hline 2 & IVB & 16 & 12 & $44,4 \%$ & 27 \\
\hline 3 & IVC & 15 & 12 & $47 \%$ & 85 \\
\hline \multicolumn{2}{|r|}{ JUMLAH } & 45 & 40 & \\
\hline
\end{tabular}

Sumber : Arsip Nilai Ulangan Harian Mata Pelajaran IPA Kelas IV Kelas A, B, C di SDN 1 Sukamulya T.A. 2019/2020

Berdasarkan tabel 1 didapatkan data yang menjelaskan bahwa 85 jumlah murid kelas IV hanya 40 murid yang nilainya sesuai KKM sedangkan terdapat 45 murid yang belum sesuai kriteria ketuntasan minimal. Jumlah murid kelas IVA yang memenuhi kriteria ketuntasan minimal berjumlah 16 murid atau sama dengan 53,3\% dari 30 murid. Jumlah peserta didik kelas IVB yang telah memenuhi KKM berjumlah 12 murid atau sama dengan $42,9 \%$ dari 28 murid. Sedangkan jumlah murid yang telah sesuai dengan kriteria ketuntasan minimal (KKM) berjumlah 12 murid atau sama dngan 44,4\% dari 27 murid. Dari data di atas menjelaskan bahwa nilainya kurang baik dan belum tuntas keseluruhan. Ketidak tuntasan

\footnotetext{
${ }^{14}$ Diah Wahyuningsih. Wawancara Dengan Penulis. SDN 1Sukamulya Kecamatan Palas Kabupaten Lampung Selatan, 21 September 2019.

${ }^{15}$ Mei Dwiyono. Wawancara Dengan Penulis. SDN 1Sukamulya Kecamatan Palas Kabupaten Lampung Selatan, 21 September 2019.

${ }^{16}$ Mastina. Wawancara Dengan Penulis. SDN 1Sukamulya Kecamatan Palas Kabupaten Lampung Selatan, 21 September 2019.
} 
ini menunjukan adanya permasalah dalam proses belajar murid yaang mempengaruhi kemampuan murid dalam berpikir kritis.

Menurut Silberman strategi belajar Jeopardy Review merupakan strategi yang dirancang seperti permainan populer di TV, pertanyaan diberikan setelah itu peserta memberikan jawaban yang benar. ${ }^{17}$ Pembelajaran ini memperbolehkan pendidik untuk mengetahui keluasan materi pelajaran yang telah pahami peserta didik serta berfungsi untuk menguatkan kembali, mengklarifikasi, menegaskan dan merangkum pokokpokok materi.

Beberapa kelebihan dari strategi pembelajaran jeopardy review, antara lain:murid dapat aktif mengikuti proses, murid bisa bekerta sama bersama kelompoknya masing-masing yang telah ditentukan pendidik, peserta dapat lebih memahami pelajaran yang sudah diberikan oleh guru, murid lebih tertarik mengikuti pembelajaran dan semangat untuk belajar karena menggunakan media papan jeopardy. ${ }^{18}$ Selain dari kelebihan, strategi pembelajaran jeopardy review juga memiliki kekurangan, antara lain: peserta didik sering gaduh untuk memperebutkan nilai sehingga terciptanya suasana yang kurang kondusif, memperlukan waktu yang cukup banyak lagi dari strategi pembelajaran lain, murid dituntut adanya kegiatan kerjasama tim/kelompok dalam proses diskusi dan permainan.

Dengan kelebihan dari strategi pembelajaran jeopardy review ini dapat membantu peserta didik kelas IV SDN 1 Sukamulya Lampung Selatan dalam mengembangkan kemampuan berpikir kritis. Melalui kegiatan aktif dan penalaran yang dituntut dalam proses pembelajaran dengan menggunakan strategi pembelajaran jeopardy review ini lah yang melatih kemampuan berpikir kritis peserta didik.

\footnotetext{
${ }^{17}$ Silberman Mel, 101 Ways To Make Training Active, 2017, 257.

18 Atikah Fauziyah, Board Game dalam Pembelajaran, (Jawa Tengah: Rumah Kita, 2019), 11.
} 


\section{METODE PENELITIAN}

Penelitian ini lakukan di SDN 1 Sukamulya Kecamatan Palas Lempung Selatan dengan model penelitian kuantitatif. Dilaksanakan pada semester genap tahun pelajaran 2019/2020 dengan sampel penelitiannya adalah murid kelas IV B dan kelas IV C SDN 1 Sukamulya dengan jumlah keseluruhan 55murid dengan mengambil materi kekayaan sumber energi di Indonesia pada tema kayanya negeriku.Variabel bebas pada penelitian ini adalah sterategi belajar jeopardy reviiew dan variabel terikatnya adalah kemampuan berpikir kritis murid kelas IV SDN 1 Sukamulya Kecamatan Palas Lampung Selatan. Peneliti memakai metode quasi experiment dan menggunakan desain nonequivaent control group desaign. Kelompok kelas penelitian dan kelas kontrol dipilih menggunakan cara acak kelas. Dalam penelitian ini, baik kelompok kelas eksperimen ataupun kelompok kelas kontrol dibandingkan. Dua kelas diberi pretest diawal pembelajaran, selanjutnya diberikan tindakan, dan kemudian diberi posttest pada akhir pembelajaran. Guna mendapatkan data yang diperlukan pada penelitian ini, peneliti menggunakan instrumen pengumpul data berupa instrumen test, observasi dan dokumentasi.

\section{HASIL DAN PEMBAHASAN TEMUAN}

Penelitin ini dilaksanakan di SDN 1 Sukamulya Kecamatan Palas Lampung Selatan pada tanggal 24 Februari 2020 sampai tanggal 24 Maret 2020. Penelitian ini dilaksanakan pada murid kelas IV B sebagai kelas penelitian dan kelas IVA menjadi kelas kontrol. Strategi belajar Jeopardy Review digunakan pada kelas eksperimen dan pada kelas kontrol peneliti menerapkan strategi belajar everyone is a teacher here. Dalam penelitin ini 55 murid menjadi sampel dalam penelitian yang terdiri dari kelas IV B dan kelas IVC SDN 1 Sukamulya Lampung Selatan. materi yang digunakan yaitu materi IPA dalam tema kayanya negeriku pada bagian subtema 1 kekayaan sumber energi di Indonesia. Kedua kelas diberikan materi yang sama yaitu tentang kekayaan sumber energi di Indonesia. Setiap kelas 
dilakukan 6 kali pertemuan yakni pertemuan pertama dilakukan untuk pretest, kemudian pertemuan kedua sampai pertemuan kelima untuk proses pembelajaran, dan pertemuan yang terakhir untuk posttest atau test akhir. Test yang diberikan dalam bentuk soal essay yang terdiri dari 10 soal. Pada setiap proses pembelajaran peneliti melakukan observasi aktivitas belajar murid dengan mengisi lembar observasi yang dilakukan oleh peneliti.

Sebelum melakukan uji hipotesis data hasil penelitian, data sebelumnya telah melalui tahap uji normalitas dan juga uji homogenitas. Uji normalitas data pada penelitian ini telah dilakukan dan hasilnya menyatakan bahwa populasi pada penelitian ini berdistribusi normal. Selain uji normalitas data penelitian ini juga telah diuji homogenitas yang hasilnya menyatakan bahwa hasil posttest kedua kelas yaitu kelas eksperimen dan kontrol adalah homogen atau sama. Selanjutnya peneliti melakukan uji hipotesis setelah data dinyatakan berdistribusi normal dan homogen. Data diuji hipotesis dengan menggunakan SPSS Statistics 17.0.

Tabel.2

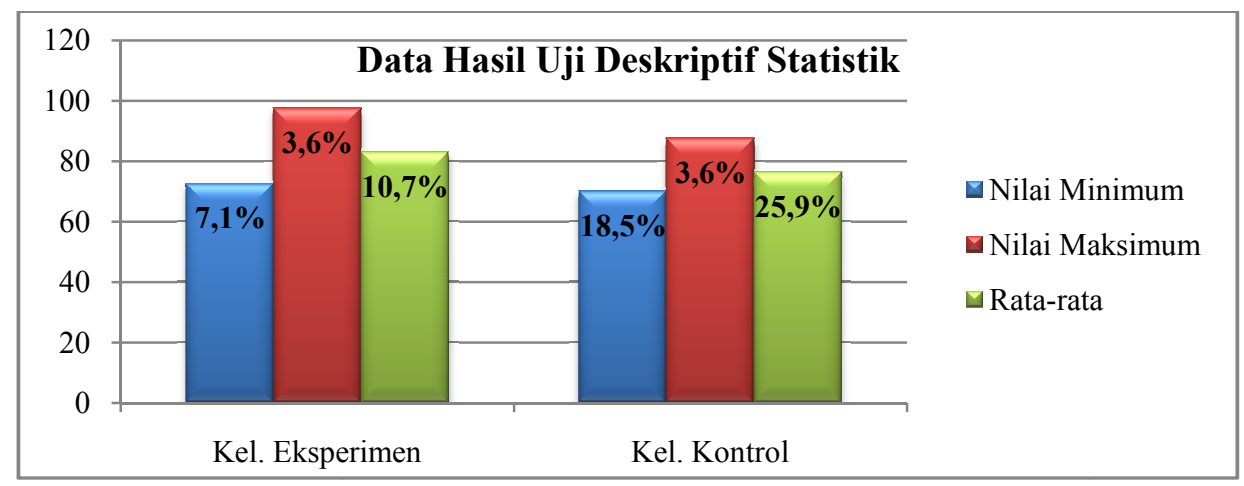

Berdsarkan tabel 2 menunjukan bahwa hasil uji deskriptif statistik menunjukan bahwa nilai kemampuan berpikir kritis murid di kelas eksperimen mencapai rata-rata sebesar 83,00 dengan memiliki jumlah murid 28 murid. Sedangkan kemampuan berpikir kritis murid di kelas kontrol mencapai rata-rata seesar 76,28 dengan memiliki jumlah murid sebanyak 27 murid. 
Tabel.3

Uji Hipotesis Kemampuan Berpikir Kritis

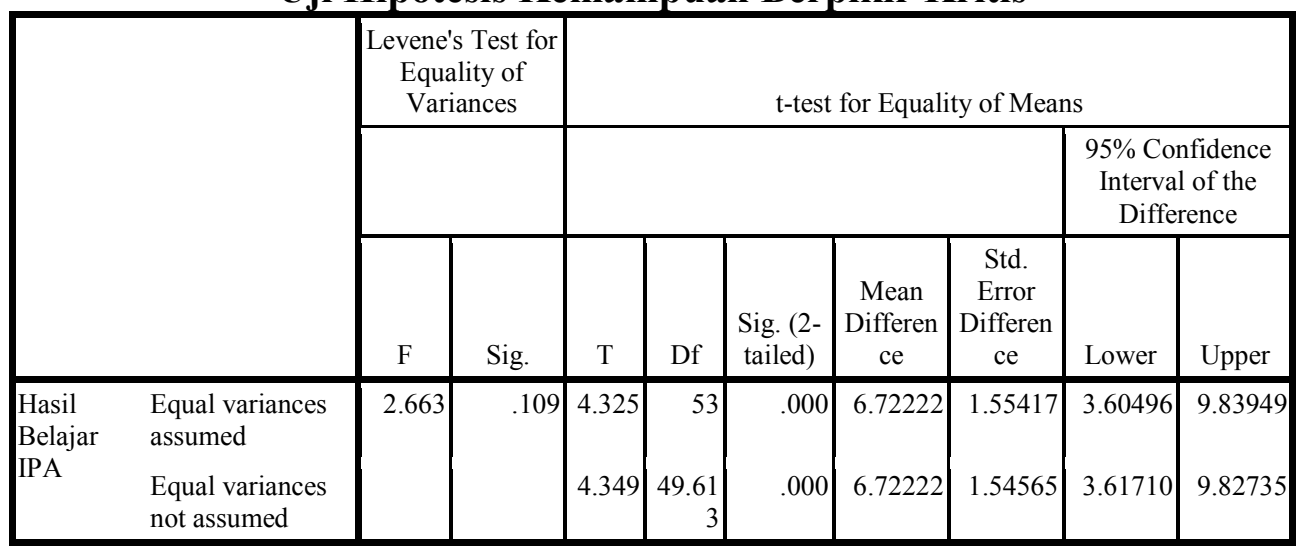

Hasil uji hipotesis data menggunakan SPSS Statistics 17.0 pada tabel 3 memperoleh signifikansi 0,000 yang berarti lebih kecil dari 0,05 $(0,000<$ 0,05). Dengan demikian $\mathrm{H}_{0}$ ditolak dan $\mathrm{H}_{1}$ diterima, sehingga dapat ditarik kesimpulan bahwa terdapat pengaruh strategi pembelajaran jeopardy review terhadap kemampuan berpikir kritis peserta didik kelas IV pada tema kayanya negeriku di SDN 1 Sukamulya.

Soal test yang dipakai pada penelitian ini yaitu soal essay yang telah disesuaikan dengan setiap indikator dari kemampuan berpikir kritis. Uji validitas, uji reliabilitas, uji tingkat kesukaran dan uji daya pembeda dilakukan untuk menguji soal essay yang akan diujikan kepada para murid. Dari hasil uji coba soal terdapat 12 butir pertanyaan dari 15 butir pertanyaan yang dapat digunakan untuk penelitian. 15 pertanyaan tersebut telah diuji cobakan keepada 30 murid kelas V SDN 1 Sukamulya.

Peneliti memakai 10 butir pertanyaan, butir pertanyaan tersebut telah sesuai dengan indikator berpikir kritis yang sudah ada dan telah mengalami uji coba soal sehingga dapat dipakai pada penelitian. 10 pertanyaan dalam bentuk essay ini dipakai untuk test awal atau pretest dan test akhir posttest. Selain menggunakan soal essay peneliti juga melakukan observasi aktivitas belajar murid dengan cara mengisi lembar observasi yang telah disesuaikan dengan indikator aktivitas belajar muid. Lembar pertanyaan dalam bentuk 
essay dan juga lembar observasi aktivitas belajar digunakan sebagai data hasil penelitian.

Sebelum melakukan uji hipotesis data hasil penelitian, data sebelumnya telah melalui tahap uji normalitas dan juga uji homogenitas. Uji normalitas data pada penelitian ini telah dilakukan dan hasilnya menyatakan bahwa populasi pada penelitian ini berdistribusi normal. Selain uji normalitas data penelitian ini juga telah diuji homogenitas yang hasilnya menyatakan bahwa hasil posttest kedua kelas yaitu kelas eksperimen dan kontrol adalah homogen atau sama. Selanjutnya peneliti melakukan uji hipotesis setelah data dinyatakan berdistribusi normal dan homogen. Data diuji hipotesis dengan menggunakan SPSS Statistics 17.0.Untuk uji hipotesis pada penelitian ini diperoleh hasil dengan memperoleh signifikansi 0,000 yang berarti lebih kecil dari $0,05(0,000<0,05)$. Dengan demikian $\mathrm{H}_{1}$ diterima dan $\mathrm{H}_{0}$ ditolak, sehingga dapat disimpulkan bahwa terdapat pengaruh strategi belajar jeopardy review terhadap kemampuan berpikir kritis murid kelas IVB pada tema kayny negeriku di SDN 1 Sukamulya.

Perbedaan terjadi pada saat proses pembelajaran yakni murid lebih aktif pada saat pembelajaran seperti lebih banyak bertanya, menjawab pertanyaan, bekerjasama dan bertanggung jawabdalam mendiskusikan informasi, dapat mengeluarkan pendapat sesuai pengalaman. Informasi yang diberikan dapat berupa pertanyaan ataupun pernyataan. Saat murid diberikan sebuah informaasi peserta didik akan terangsang supaya mulai berpikir dengan daya berpikir pada setiap murid berbeda-beda.

Perbedaan tahap berpikir setiap murid ini membuat murid membutuhkan satu sama lain untuk mendapat pengetahuan lebih dari informasi yang dibagikan. Berbagi pengetahuan antara satu murid dengan murid lainnya dilakukan menggunakan cara diskusi dimana peneliti memberikan informasi pancingan berupa pertanyaan, sehingga murid dituntut agar dapat menganalisis informasi yang terdapat pada pertanyaan sehingga dapat menjawab pertanyaan yang telah diberikan dan jawaban 
yang diberikan telah didiskusikan terlebih dahulu sengan teman sekelompoknya. Diskusi antar kelompok ini menciptakan kompetisi yang dapat membuat murid lebih semangat serta aktif pada proses belajar. Hal ini sesuai dengan tujuan strategi belajar jeopardy review yang telah dirancang untuk memberikan suatu kesempatan kepada setiap murid agar mampu meningkatkan kemampuan berpikir mereka masing-masing.

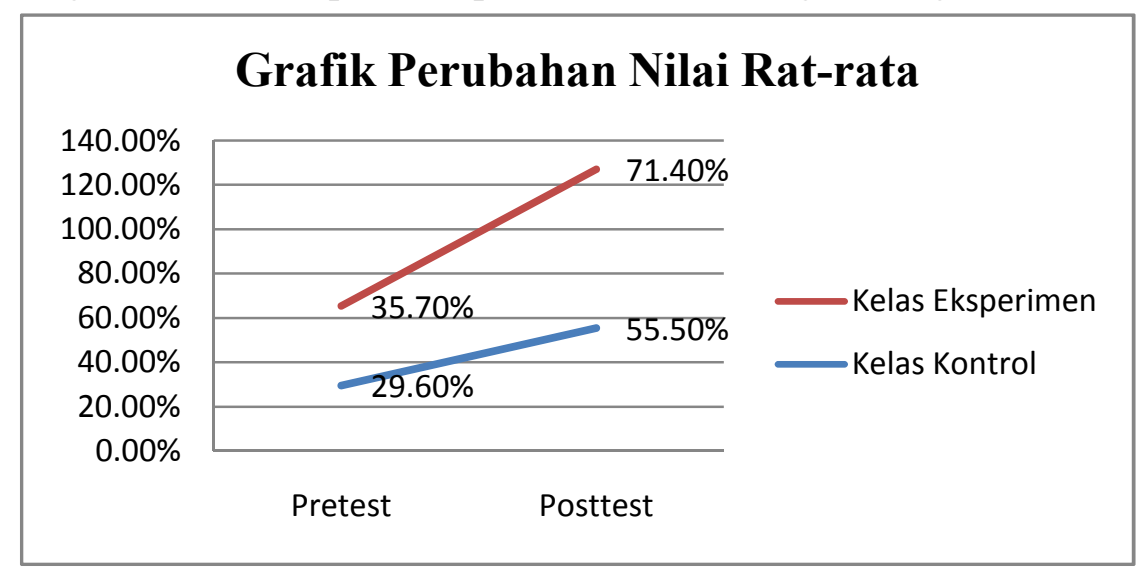

Pada grafik perubahan nilai rata-rata siswa siswi kelas IVB dan kelas IVC SDN 1 Sukamulya Lampung Selatan menjelaskan bahwa terdapat perubahan yang signifikan dari nilai rata-rata pada saat pretest di kelas eksperimen yaitu $35,70 \%$ dan posttest nya mencapai $71,40 \%$. Sedangkan pada kelas kontol nilai rata-rata pretest sebesar $29,60 \%$ dan nilai rata-rata posttest sebesar 55,50\%. Jadi dapat dipahami bahwa penggunaan strategi pembelajaran jeopardy review dalam proses pembelajaran memberikan pengaruh besar terhadap kemampuan berpikir kritis murid.

Meningkatnya kemampuan berpikir kritis murid setelah diterapkannya strategi pembeajaran Jeopardy Review di sebabkan oleh meningkatnya pemahaman murid tema kayanya negeriku yang telah diajarkan, pada proses pembelajaran murid terlihat lebih aktif, dan proses belajar memberikan kesempatan kepada murid supaya saling bertukar pikiran bersama temannya, mengemukakan dan mengembangkan ide-ide untuk menelesaikan masalah, mnjawab pertanyaan yang diberikan guru saat 
prosesbelajar, keantusiasan murid dalam ikut serta dalam pembelajaran sehingga menemukan solusi untuk menyelesaikan masalah yang sesuai dalam diskusi kelompoknya. Dengan hal ini pendidik memberikan kesempatan murid untuk mendapatkan informasi yang detail melalui kegiatan berpikir yang kritis. Murid dapat memahami unformasi baru melalui diskusi, mengeluarkan pertanyaan, dana memahami pendapat murid lainnya.

Peneliti juga menemukan beberapa kendala yang telah dialami pada saat beljar mengajar berlangsung yang dihadapi pada saat proses pembelajaran yakni murid yang kurang mampu bekerja sama dalam kelompoknya dengan baik, hal ini disebabkan unsur ingin menang sendiri dansifat individual beberapa murid . Kendala ini dialami peneliti pada saat diskusi kelompok berlangsung, akan tetapi kendala ini dapat diatas dengan cara menentukan kapten tim (kelompok) pada saat permainan jeopardy review berlangsung. Pada saat permainan berlangsung peserta didik dituntut agar dapat bekerja sama untuk menjawab pertanyaan yang telanh diberikan kepada murid dan setelah itu kapten tim (kelompok) menyampaikan jawaban yang sudah didiskusikan bersama-sama, sehingga tidak terjadi rebutan ingin menjawab dari masing-masing individu. Sistem perwakilan dalam menjawab pertanyaan ini mengurangi sikap ingin menang sendiri dari setiap murid sehingga murid tetap semangat, aktif serta antusias pada saat mengikuti proses belajar sehingga materi kayanya negeriku yang diajarkan dapat dipahami dengan baik murid dan dapat meningkatkan kemampuan setiap murid untuk berpikir kritis. 


\section{SIMPULAN}

Hasil penelitian ini yaitu $\mathrm{H}_{0}$ ditolak dan $\mathrm{H}_{1}$ diterima, ditunjukan dengan hasil analisis data serta uji hipotesis yang sudah dilakukan dan memperoleh nilai signifikansi $0,000<0,05$. Jadi dapat disimpulkan bahwa terdapat pengaruh strategi belajar Jeopardy Review terhadap kemampuan berpikir kritis murid pada tema kayanya negeriku kelas IV B SDN 1 Sukamulya pada mata pelajaran IPA. Pengaruh strategi belajar Jeopardy Review terhadap kemampuan berpikir kritis murid juga ditunjukan dengan perubahan nilai rata-rata yang terjadi pada kelas eksperimen yaitu pada saat pretest sebesar $35,70 \%$ sedangkan pada saat posttest bertambah menjadi $71,40 \%$. Penambahan presentase nilai rata-rata siswa-siswi ini menunjuknya adanya pengaruh strategi belajar Jeopardy Review terhadap kemampuan berpikir kritis murid-murid kelas IVB SDN 1 Sukamullya Lampung Selatan.

Pembelajaran dengan menggunakan strategi pembelajaran jeopardy review dapat dipakai sebagai cara lain untuk. Kemudian, dalam proses belajar mengajar seharusnya pihak sekolah serta pendidik menyiapkan fasilitas yang sesuai dengan proses belajar berlangsung seperti alat belajar ataupun bahan ajar/belajar yang nantinya akan dipakai dalam proses belajar agar proses belajar mengajar dengan memakai strategi belajar jeopardy review bisa berjalan dengan baik sehingga dapat mencapi tujuan pembelajaran. 


\section{DAFTAR PUSTAKA}

Abu Ahmadi, Nur Uhbiyati. Ilmu Pendidikan. Jakarta: Rineka Cipta. 2015.

Alec, Fisher. “Berpikir kritis: Sebuah Pengantar”. Jakarta: Erlangga. 2017.

Aris, Shoimin. 68 Model Pembelajaran Inovatif dalam Kurikulum 2013, Yogyakarta: Ar-Ruzz Media. 2017.

Avinda Fridanianti, Heni Purwati, and Yanuar Hery Murtianto, 'Analisis Kemampuan Berpikir Kritis Dalam Menyelesaikan Soal Aljabar Kelas Vii Smp N 2 Pangkah Ditinjau Dari Gaya Kognitif Reflektif Dan Kognitif Impulsif', AKSIOMA: Jurnal Matematika Dan Pendidikan Matematika, 9.1 (2018), 11.

Dwiyono, Mei, Wawancara dengan penulis. SDN 1Sukamulya Kecamatan Palas Kabupaten Lampung Selatan, 21 September 9.

Eni Fariyarul Fahyuni, Nurdyansyah. Inovasi Model Pembelajaran Sesuai Kurikulum 2013. Sidoarjo: Nizamia Learning Center. 2016.

Atikah, Fauziyah. Board Game dalam Pembelajaran. Jawa Tengah: Rumah Kita, 2019.

Friedman, Harry. Classroom Jeopardy Teacher's Guide, Annals of Improbable Research, 2016.

Waseso, Hendri Purbo. 'Studi Kritis Terhadap Kurikulum MI/SD 2013', Jurnal Terampil, 4 (2017), 175.

Karim, Muh. Kadri, 'Pengaruh Penerapan Game Jeopardy Dalam Pembelajaran Remedial Terhadap Aktivitas Dan Hasil Belajar Mata Pelajaran Ips Di Sd', Jurnal Review Pendidikan Dasar: Jurnal Kajian Pendidikan Dan Hasil Penelitian, 5.1 (2019), 858.

Mastina, Wawancara dengan penulis, SDN 1Sukamulya Kecamatan Palas Kabupaten Lampung Selatan, 21 September 2019.

Melvin Silberman, Elaine Biech, Active Training (A Handbook of Techniques, Designs, Case Examples and Tips), CIRED - Open Access Proceedings Journal, 2015.

Moh Khoerul Anwar, 'Pembelajaran Mendalam Untuk Membentuk Karakter Siswa Sebagai Pembelajar', 02.2 (2017), 97. 
Muhammad FikriHasan, Agus Suyatna, and Wayan Suana, 'Development of Interactive E-Book on Energy Resources to Enhance Student's Critical Thinking Ability', Tadris: Jurnal Keguruan Dan Ilmu Tarbiyah, 3.2 (2018), 109.

Nazhifah mesi Putri dan Fitrawati, 'The Use Of Jeopardy Game To Teach Vocabulary To Young Learner', 12.9 (2018), 3-6

Neil Browne M., Stuart M. Keeley. Pemikiran Kritis (Panduan Untuk Mengajukan dan Menjawab Pertanyaan Kritis). Jakarta: PT Indeks. 2015.

Nursida. 'Perbandingan Strategi Pembelajaran Aktif Tipe Topical Review Dan Tipe Jeopardy Review Terhadap Pemahaman Konsep Matematika Siswa Kelas X Sman 16 Makassar', 2017.

Azizah, Reni Nur. Pengaruh Pendekatan Proses Dan Kemampuan Berfikir Kritis Terhadap Hasil Belajar Pada Mata Pelajaran IPA Di Kelas V MI Terpadu Muhammadiyah Sukarame, 2018.

Ridha Unnafi Walfajri. Nyoto Harjono. 'Upaya Peningkatan Kemampuan Berpikir Kritis Dan Hasil Belajar Tematik Melalui Model Problem Based Learning (Pbl) Kelas V Sd'. NATURALISTIC : Jurnal Kajian Penelitian Pendidikan Dan Pembelajaran, 3.2 (2019), 75.

Sesmiarni, Zulfani. 'Kecerdasan Jamak Dalam Pembelajaran IPA Di Sekolah Dasar', TERAMPIL Jurnal Pendidikan Dan Pembelajaran Dasar, 1.2 (2014), 180.

Silbermen Mel. "Active Learning: 101 Strategi Pembelajaran Aktif", Yogyakarta: Pustaka Insan Madani. 2019.

Silberman, Mel. 101 Ways To Make Training Active, 2017

Silberman, Mel. Elaine Biech, and Carol Auerbach, Active Training, Active Training, 2015.

Susanto Ahmad, Teori Belajar dan Pembelajaran di Sekolah Dasar. Jakarta: Kencana. 2016.

Syarif Sumantri, Mohamad. Strategi Pembelajaran Teori Dan Praktik Di Tingkat Pendidikan Dasar. Jakarta: Rajawali Pers. 2016.

Tim Redaksi. Undang-Undang Nomor 20 Tahun 2003 Tentang Sistem Pendidikan Nasional. Jakarta: Sinar Grafika. 2016. 
Hidayat, Tofik. 'Studi Kasus Penggunaan Permainan Tematit Jeopardy Dalam Belajar Bahasa Inggris', Journal of Chemical Information and Modeling, 53.9 (2017), 89.

Samatowa, Usman. Pembelajaran IPA di Sekolah Dasar. Jakarta: PT Indeks. 2016.

Wahyuningsih, Diah, Wawancara dengan penulis. SDN 1Sukamulya Kecamatan Palas Kabupaten Lampung Selatan, 21 September 2019. 